\title{
Neurotransmitter visualization in schizophrenia
}

\author{
James Robert Brašić \\ School of Medicine, The Johns Hopkins University, Baltimore, Maryland \\ Correspondence: James R. Brašić. Address: Johns Hopkins Outpatient Center, 601 North Caroline Street, Room 3245, \\ Baltimore, Maryland 21287-0807, USA. Email: brasic@jhmi.edu. \\ Received: June 30, 2012 \\ DOI: $10.5430 / j b g c . v 3 n 2 p 30$ \\ Accepted: August 7, $2012 \quad$ Online Published: February 22, 2013 \\ URL: http://dx.doi.org/10.5430/jbgc.v3n2p30
}

\section{Abstract}

Background: Although the history, interview, and examination of the patient provide the foundation for the diagnosis of schizophrenia, nuclear neuroimaging investigations constitute promising tools to elucidate the pathophysiology of schizophrenia and other neuropsychiatric disorders. Imaging studies of neuroreceptors constitute research tools to investigate the role of dysfunction of the acetylcholinergic, dopaminergic, glutamatergic, serotonergic, cannabinoid, opioid, and nicotinic systems in the pathogenesis and pathophysiology of schizophrenia and related conditions.

People with the phenotype of the clinical syndrome of schizophrenia likely represent multiple distinct genotypes with poorly characterized biological traits. Thus, the population of people manifesting the clinical syndrome of schizophrenia likely contains several heterogeneous biological subgroups yet to be specified.

The dopamine hypothesis of schizophrenia proposes that the positive symptoms result from an excess of intrasynaptic dopamine, an excitatory neurotransmitter, and the negative symptoms result from a deficit of intrasynaptic dopamine. Accordingly, a group of people with schizophrenia likely have reduced intrasynaptic dopamine in the tonic, resting, basal state, and increased intrasynaptic dopamine in the excited, aroused, phasic state.

Additionally, the glutamate hypothesis of schizophrenia suggests that dysfunction of glutamate, another excitatory neurotransmitter, in the prefrontal region results in excessive concentrations of dopamine in the striata resulting in the positive symptoms of schizophrenia.

Methodology/Principal Findings: Published research about the nuclear neuroimaging techniques to identify neurotransmitters in people with schizophrenia are reviewed.

Conclusions/Significance: Future research including neuronuclear imaging and genetic evaluations is needed to characterize the biological subgroups of people with the clinical syndrome of schizophrenia. Neuronuclear imaging studies will likely refine the measurement of neurotransmitters in the presynaptic, synaptic, and postsynaptic regions in people with schizophrenia and healthy people. Imaging studies of neuroreceptors during the administration of putative therapeutic agents for schizophrenia will help determine the optimal dose. In the future the research findings summarized in this article will likely be translated into clinical practice.

\section{Key words}

Dopamine, Positron-emission tomography, Psychotic disorders, Serotonin, Single-photon emission-computed tomography 


\section{Introduction}

The history of the patient and the interview and examination of the patient constitute the foundations for the diagnosis of schizophrenia. Schizophrenia cannot currently be diagnosed by imaging studies. Specifically positron-emission tomography (PET) and single-photon emission-computed tomography (SPECT) are not currently indicated in the clinical evaluation of people with schizophrenia. A structural imaging study of the brain is indicated in the diagnostic evaluation of patients with suspected schizophrenia to rule out treatable neurological disorders. Nevertheless, imaging studies of neuroreceptors in the living human brain provide research tools to (1) identify dysfunction of dopaminergic, serotonergic, glutamatergic, and acetylcholinergic systems that play a role in the pathogenesis and pathophysiology of schizophrenia and (2) measure neuroreceptor occupancy before and after the administration of putative therapeutic agents to determine optimal doses maximizing beneficial effects and minimizing adverse effects. Since an altered mental status commonly characterizes the presenting clinical picture of a person with schizophrenia, a structural imaging study of the brain, e.g., magnetic resonance imaging (MRI) or x-ray computed tomography (CT), is indicated to rule out a treatable lesion, such as bilateral subdural hematomata and parasaggital meningeomas ${ }^{[1,2]}$. In time PET and SPECT imaging studies of neuroreceptors likely will become clinical tools to identify deficits in people with schizophrenia and to monitor the effects of therapeutic and other interventions.

Brain imaging techniques are broadly divided into two groups, structural and functional. Structural techniques illustrate the anatomical portions of the brain and related structures. Structural imaging techniques of the brain include x-ray CT, MRI, MRS, and radiography (x-rays). Functional imaging techniques illustrate the physiological portions and divisions of the brain and associated organs. Functional imaging techniques include PET and SPECT ${ }^{[2,3]}$. Both structural and functional imaging techniques have contributed to the knowledge of the pathogenesis and pathophysiology of schizophrenia.

Structural imaging studies have identified several alterations in the brains of people with schizophrenia. For example, MRI, a structural imaging technique, has demonstrated bilateral reductions in the volume of the medial temporal lobes of people with schizophrenia ${ }^{[4]}$. MRI demonstrated that the gray matter in the head of the caudate nucleus is reduced in people with first episodes of schizophrenia and absent in people with chronic schizophrenia ${ }^{[5]}$. Structural imaging procedures can well delineate subtle alterations in anatomical structures, but not the physiological processes mediated by those structures.

Functional imaging procedures to visualize neuroreceptors in the brain include SPECT and PET. The utilization of function imaging procedures can be limited by the availability of the necessary instrumentation and manpower. Some functional imaging techniques are widely available. For example, (1) regional cerebral blood flow (rCBF) and (2) glucose metabolism can be measured with scanners that are widely available in hospitals. $\mathrm{CBF}$ can be estimated by measuring cerebral perfusion utilizing SPECT utilizing radioligands containing ${ }^{123} \mathrm{I}$ and ${ }^{99 \mathrm{~m}} \mathrm{Tc}$, such as $\left.{ }^{99 \mathrm{~m}} \mathrm{Tc}\right]$ hexamethylpropyleneamine oxime ( $\left.\left[{ }^{99 \mathrm{~m}} \mathrm{Tc}\right] \mathrm{HMPAO}\right)$. Since ${ }^{99 \mathrm{~m}} \mathrm{Tc}$ is widely available, $\mathrm{rCBF}$ can be readily estimated with SPECT on a clinical basis ${ }^{[6]}$. Additionally, because $\left[{ }^{18} \mathrm{~F}\right]$ has a half-life of two hours, then $\left[{ }^{18} \mathrm{~F}\right]$ radiotracers can be transported to facilities within a radius of approximately a hundred miles of manufacture. Thus, 2-deoxy-2- $\left[{ }^{18} \mathrm{~F}\right]$ fluoro-D-glucose positron-emission tomography ( $\left.\left[{ }^{18} \mathrm{~F}\right] \mathrm{FDG} \mathrm{PET}\right)$ is widely performed in clinical settings to assess the metabolism of glucose in the brain and other organs ${ }^{[6,7]}$. $\left[{ }^{18}\right.$ F]FDG PET can be administered in many settings throughout the world. Standard clinical techniques to measure $\mathrm{rCBF}$ and glucose metabolism are generally available. Functional imaging procedures to assess $\mathrm{rCBF}$ and glucose metabolism in the brain are popular tools available in many community hospitals and other health facilities.

In contrast to techniques to estimate $\mathrm{rCBF}$ and glucose metabolism, tools to evaluate neuroreceptors are often limited to highly specialized tertiary healthcare facilities. Because PET with ${ }^{11} \mathrm{C}$ requires an adjacent cylclotron due to the short (approximately 20 minutes) half-life of ${ }^{11} \mathrm{C},\left[{ }^{11} \mathrm{C}\right]$ neuroreceptor PET imaging studies are restricted to PET centers equipped with a cyclotron and specially trained radiochemists. Figure 1 illustrates a state-of-the-art tomography 
instrument to provide high resolution images of the brain for research purposes ${ }^{[8]}$. Brain imaging techniques exist to demonstrate a vast array of receptors in the brain, including dopamine, serotonin, and acetylcholine. A panoply of neuronal receptors can be visualized by neuronuclear techniques ${ }^{[2]}$.

Nuclear neuroimaging identifies the functions of several sites in the process of neurotransmission. Neurotransmission occurs when a neurotransmitter, a chemical compound emitted by a presynaptic neuron into a synapse, binds to the receptor site on the postsynaptic neuron to elicit an action from the postsynaptic neuron ${ }^{[9]}$. The neurotransmitter particles remaining in the synapse are then drawn up by the transporter for the neurotransmitter in the presynaptic neuron to be packaged into neurotransmitter parcels for rerelease by the presynaptic neuron ${ }^{[2]}$. Typically there are unique radiotracers to bind to the neurotransmitter, the receptor of the neurotransmitter, and the transporter of the neurotransmitter. While a vast range of radiotracers are theoretically possible, only a few have demonstrated the safety and the efficacy required to utilize with human subjects. The absence of human radiotracers to demonstrate all neurotransmitters in the presynaptic, intrasynaptic, and postsynaptic locations represents a limitation of imaging for neuroreceptors. Many crucial locations cannot currently be demonstrated utilizing available tools. In other words, contemporary imaging tools provide incomplete data to estimate neuroreceptors in the living human brain.

Figure 1. A high resolution research tomograph (HRRT) provides state-of-the-art positronemission tomography of the brain. A patient comfortably lies in the scanner for hours without sedation. The instrument produces images with a resolution approaching $2 \mathrm{~mm}^{[8]}$.

Note. Photo provided courtesy of Dr. Melinda Roberson, Division of Nuclear Medicine, The Russell $\mathrm{H}$. Morgan Department of Radiology and Radiological Science, The Johns Hopkins University School of Medicine, Baltimore, Maryland.

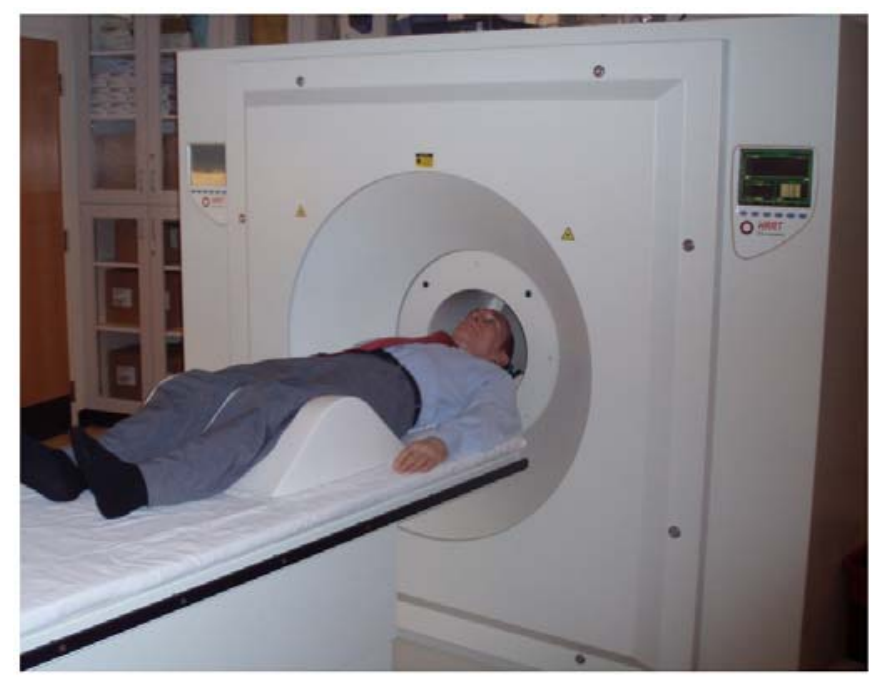

Since there exist several subtypes of neurotransmitter receptors, there are often unique radiotracers to bind to specific subtypes of neurotransmitter receptors. While there are radiotracers to identify transporters for dopamine and serotonin and multiple subtypes of receptors for dopamine and serotonin, there are no radiotracers for dopamine and serotonin. Thus, the concentrations of dopamine and serotonin in the synapse must be estimated indirectly from quantitative measurements of the density and the distribution of the dopamine and serotonin transporters and the various subtypes of dopamine and serotonin receptors ${ }^{[2]}$. Thus, published studies contain inferences about the intrasynaptic concentrations of neurotransmitters based on data about related compounds. The imaging studies of neurorceptors in schizophrenia contain uncertainty due to the indirect nature of the available data.

There exist contradictions and inconsistencies in multiple imaging studies of neuroreceptors in schizophrenia. The apparent discrepancies in the published imaging studies of neuroreceptors can be explained by recognizing that people with the clinical syndrome of schizophrenia likely constitute a heterogeneous group of individuals who manifest multiple biological subtypes, each with different etiologies. Schizophrenia is a syndrome, a constellation of symptoms, the subjective complaints of the patient, and signs, the objective observations of the examiner, along with a particular set of laboratory findings, along with a known family history, and a natural course ${ }^{[10]}$. The syndrome of schizophrenia is likely the final common pathway of many different causes. In other words, people with distinct unknown genotypes present the 
phenotype of the clinical syndrome of schizophrenia. Thus, several distinct biological subgroups all present with the clinical syndrome of schizophrenia. Imaging studies of neuroreceptors constitute a means to distinguish biological subgroups of individuals with the clinical syndrome of schizophrenia. Since the criteria for the nomenclature of biological subgroups of people with schizophrenia is currently being reformulated, there are gaps in the knowledge of the roles of neuroreceptors in schizophrenia. By means of research in the roles of neuroreceptors in schizophrenia, the apparent discrepancies in the current state of knowledge will be resolved. This article contains a representation of the current state of knowledge of imaging studies of neuroreceptors in schizophrenia.

Since the 1980s neuroreceptor imaging by means of both SPECT and PET revolutionized the in vivo study of schizophrenia with major contributions to our understanding of both the pathophysiology and the pharmacology of schizophrenia. The early imaging studies of cerebral blood flow and glucose metabolism in the brains of people with schizophrenia suggested hypofrontality, i.e., reduced cerebral blood flow and glucose metabolism in the frontal lobes ${ }^{[1]}$. Human nuclear neuroimaging began with the visualization of the human brain after the administration of the neuroleptic spiroperidol labeled in vivo with $\left[{ }^{11} \mathrm{C}\right]$ methyl iodine ${ }^{[12]}$ and $\left[{ }^{18} \mathrm{~F}\right]$ moieties. Then nuclear neuroimaging progressed with the utilization of PET after the administration of $\left[{ }^{11} \mathrm{C}\right]$ raclopride, another antagonist of the dopamine D2 and D3 receptors. Both 3- $N-\left[{ }^{11} \mathrm{C}\right]$ methylspiperone $\left(\left[{ }^{11} \mathrm{C}\right] \mathrm{NMSP}\right)$ and $\left[{ }^{11} \mathrm{C}\right]$ raclopride as radiotracers have enhanced our understanding of dopamine D2 and D3 receptors. Since both $\left[{ }^{11} \mathrm{C}\right]$ NMSP and $\left[{ }^{11} \mathrm{C}\right]$ raclopride are displaced by unlabeled antipsychotic agents, e. g., haloperidol, both radiotracers are valuable agents to estimate the occupancy of D2-like dopamine receptors by established antipsychotic medications and by novel agents ${ }^{[11]}$. The same procedure is commonly utilized to estimate therapeutic drug dose levels of established and novel medications. Furthermore, neuronuclear imaging illustrated the benefits from utilizing results drawn from the joining of basic psychopharmacology, central nervous system nuclear medicine methodology, and in vivo neuropsychiatric applications ${ }^{[11,13,14]}$.

Evaluation of the role of the dopamine system in schizophrenia was followed by the assessment of the effect of the serotonin system in this disorder and related conditions. Investigation of the effects of atypical antipsychotics including clozapine (Clozaril), risperidone (Risperdal), and olanzapine (Zyprexa) on the dopamine and serotonin systems is crucial because these agents have important effects on both systems ${ }^{[11]}$.

\section{The dopamine hypothesis of schizophrenia}

The recognition that dopamine, an excitatory neurotransmitter, likely plays a role in the pathogenesis, the pathophysiology, and the pharmacotherapy of schizophrenia represents a key finding on the path to alleviate the disorder. Dopamine is an endogenous neurotransmitter normally occurring throughout the human body. To enable communication between neurons, presynaptic neurons release dopamine into the synapse to travel to postsynaptic neurons to bind to the dopamine receptors to then stimulate the postsynaptic neurons. The dopamine remaining in the synapse is then taken back into the presynaptic neuron by the dopamine transporter to be placed in packets to be released when needed ${ }^{[9]}$.

Considerable lines of evidence converge to confirm the notion that alterations in the density, the distribution, and the function of D2 and D3 neuroreceptors in the brain play a role in the pathogenesis and the pathophysiology of schizophrenia ${ }^{[13-17]}$. The dopamine hypothesis of schizophrenia proposes that schizophrenia results from dysfunction of dopaminergic neurotransmission in the brain ${ }^{[16-20]}$. Likely there exist multiple distinct biological subtypes of people with schizophrenia. The disparate findings of published studies of neuroreceptors in people with schizophrenia probably result from the differences among distinct unknown biological subgroups of the population of people with the clinical syndrome of schizophrenia. A biological subgroup of people with schizophrenia appears to have a reduced basal, tonic level of intrasynaptic dopamine resulting in hyperfunction of the dopaminergic system in schizophrenia ${ }^{[20,21]}$. The positive symptoms of schizophrenia, presenting in adolescence and young adulthood, including hallucinations, delusions, and disordered thought processes, are hypothesized to result from an intermittent phasic excess of dopamine in the synapse in a subgroup of people manifesting the clinical syndrome of schizophrenia ${ }^{[20,21]}$. The negative symptoms of schizophrenia, including apathy, withdrawal, and lack of motivation, are hypothesized to result from an intermittent tonic deficit of 
dopamine in the synapse in a subgroup of people with the clinical syndrome of schizophrenia ${ }^{[21]}$. Thus, the population of people with schizophrenia actually includes multiple distinct unknown biological groups each with distinctive patterns of dysfunction of neuroreceptors reflected in unique patterns of neuroreceptor density and distribution in specific portions of the brain. A goal of imaging studies of neuroreceptors in schizophrenia is to distinguish the unique identifying characteristics of each of the biological groups of the population of people with the clinical syndrome of schizophrenia.

The discovery that the positive symptoms of schizophrenia are alleviated when $60 \%$ to $80 \%$ of dopamine D2-like neuroreceptors in the brain are occupied by antipsychotic drugs demonstrated by PET ${ }^{[6,15,22,23]}$ represents a major advance in the development of novel drugs to treat people with schizophrenia. PET allows clinicians to determine the likely optimal dose of dopamine D2 receptor blocking drugs to produce a therapeutic effect with minimal adverse effects ${ }^{[17]}$. Doses of typical antipsychotics resulting in greater than $80 \%$ occupancy of dopamine D2 receptors in the brain demonstrated by PET may increase the risk of the development of tardive dyskinesias, other movement disorders, and other adverse events likely with higher dosages ${ }^{[6,13,17,22,23]}$. Thus, imaging studies of the density and the distribution of dopamine D2 receptors before and after the administration of putative therapeutic agents for schizophrenia constitute a tool to identify likely therapeutic doses of novel agents.

Additionally the hypothesis that dopaminergic overactivity plays a role in the cognitive impairments of some people with schizophrenia is confirmed by animal studies. For example, impairments of working memory occur in mice with reversibly increased amounts of dopamine D2 receptors in the brain ${ }^{[24]}$. These findings provide evidence that the phasic dopaminergic overactivity characteristic of a biological subgroup of the population of people with schizophrenia may lead to chronic impairments in working memory ${ }^{[16,24]}$. In rats dopamine D1 and D2 receptors differentially modulate the inhibition of gamma amino butyric acid (GABA) in prefrontal cortical pyramidal neurons ${ }^{[25]}$. This finding provides a possible mechanism for the memory deficits of a biological subgroup of the population of people with schizophrenia. These observations may provide the basis for a hypothesis about the likely prefrontal dysfunction of humans with schizophrenia to be tested through neuroimaging experiments.

\subsection{PET imaging measurement of absolute dopamine D2-like receptor density $\left(B_{\max }\right)$}

The study of the binding of dopamine (DA) D2-like receptors is typically accomplished by means of a single PET or SPECT scan at high specific activity with an injection with low mass and nonpharmacologic dose to measure the binding potential (BP), the ratio of the absolute receptor density $\left(\mathrm{B}_{\max }\right)$ to the radioligand equilibrium dissociation constant $\left(\mathrm{K}_{\mathrm{D}}\right)$. The $\mathrm{BP}$ is also the product of the $\mathrm{B}_{\max }$ and the affinity, as follows:

$$
\mathrm{BP}=\left(\mathrm{B}_{\max }\right) /\left(\mathrm{K}_{\mathrm{D}}\right)=\left(\mathrm{B}_{\max }\right) \times[1 /(\mathrm{KD})]=\left(\mathrm{B}_{\max }\right) \times \text { affinity }(\text { Equation } 1)^{[26]}
$$

The measurement of the absolute dopamine D2-like receptor density $\left(\mathrm{B}_{\max }\right)$ by means of PET scans following the administration of high- and low-specific activity radiotracers for the dopamine D2-like receptor has been accomplished using two main classes of radiotracers. The first class of radiotracers to visualize D2 or D3 receptors in the brain includes butyrophenones such as $\left[{ }^{11} \mathrm{C}\right]$ NMSP and $\left[{ }^{18} \mathrm{~F}\right]$ spiperone. The second class of radiotracers to visualize D2-like receptors in the brain includes radiolabeled benzamides such as $\left[{ }^{11} \mathrm{C}\right]$ raclopride, $\left[{ }^{18} \mathrm{~F}\right]$ fallypride $\left(\left[{ }^{18} \mathrm{~F}\right] \mathrm{FP}\right)$, and $\left[{ }^{123} \mathrm{I}\right]-$ iodobenzamide ([$\left.\left.{ }^{123} \mathrm{I}\right] \mathrm{IBZM}\right)$.

\subsection{Estimation of absolute dopamine D2-like receptor density}

Dopamine D2-like receptor densities have been shown to be elevated in brain tissue from people with schizophrenia by means of in vitro techniques including tissue homogenates in test tubes and autoradiography, the estimation of dopamine D2-like receptor density on brain slices placed on x-ray film. In the 1970s post mortem brain tissue of people with schizophrenia revealed elevations of dopamine D2-like receptor densities in the striata. Since the amount of prior treatments including neuroleptics, dopamine-receptor blocking drugs, administered to the people with schizophrenia was 
unknown in these studies, the possible confounding effects of prior medication treatment was uncertain. The advent of PET in humans ${ }^{[12]}$ provided the opportunity to measure absolute dopamine D2-like receptor density, not merely the binding potential, in living humans with schizophrenia whose treatment histories with neuroleptics and other medications was known. Indeed the first studies to measure absolute dopamine D2-like receptor density utilized a saturation procedure which required two or more PET scans to establish independently the measurements of the receptor density $\left(\mathrm{B}_{\max }\right)$ and the binding affinity $\left(\mathrm{K}_{\mathrm{D}}\right)^{[27,28]}$.

In contrast to the typical approach of measuring the binding potential of dopamine D2-like neuroreceptors, techniques using two PET scans have the unique ability to measure the absolute receptor density $\left(\mathrm{B}_{\max }\right)$. The measurement of absolute $\mathrm{B}_{\max }$ can be carried out by performing two brain scans with the administration of $\left[{ }^{11} \mathrm{C}\right]$ raclopride or $\left[{ }^{11} \mathrm{C}\right] \mathrm{NMSP}$, with the second scan performed after a known potent dose of a unlabeled (nonradioactive) D2-like DA receptor antagonist such as unlabeled raclopride itself or haloperidol, respectively, to reduce some of the binding. Following some additional mathematical modeling, these results then provide an estimate of the $B_{\max }$ and $K_{D}$ (Equation 1) ${ }^{\text {[26] }}$. PET demonstrated elevations of absolute dopamine D2-like receptor density $\left(\mathrm{B}_{\max }\right)$ in people with schizophrenia ${ }^{[28]}$ to confirm the results of autoradiography and in vitro homogenate studies. In general, the measurements of absolute dopamine D2-like receptor density $\left(\mathrm{B}_{\max }\right)$ in people with schizophrenia ${ }^{[28]}$ tend to show elevations ranging from small to as much as a threefold increase with $\left[{ }^{11} \mathrm{C}\right] \mathrm{NMSP}$.

Determination of receptor occupancy with two scans with different concentrations of radioligands provides the minimal data to estimate the absolute receptor density $\left(\mathrm{B}_{\max }\right)$. For example, the absolute dopamine $\mathrm{D} 2$ receptor density $\left(\mathrm{B}_{\max }\right)$ can be estimated by two PET scans after the administration of two different known concentrations of $\left[{ }^{11} \mathrm{C}\right]$ raclopride ${ }^{[29]}$. Typically PET scans are performed after the administration of $\left[{ }^{11} \mathrm{C}\right]$ raclopride of high- and low-specific activity. After the administration of high-specific activity $\left[{ }^{11} \mathrm{C}\right]$ raclopride, maximal radioligand occupancy of the dopamine D2 receptors occurs. Low-specific activity $\left[{ }^{11} \mathrm{C}\right]$ raclopride is actually prepared by mixing a known volume of a known concentration of high-specific activity $\left[{ }^{11} \mathrm{C}\right]$ raclopride (hot) and a much larger volume of nonradioactive raclopride (cold). When low-specific activity $\left[{ }^{11} \mathrm{C}\right]$ raclopride is administered to the patient, then most of the available dopamine D2-like receptors are occupied by nonradioactive cold raclopride and a few of the available dopamine D2-like receptors are occupied by radioactive hot $\left[{ }^{11} \mathrm{C}\right]$ raclopride. Therefore, $\left[{ }^{11} \mathrm{C}\right]$ raclopride occupies far more dopamine D2 receptors after the administration of high-specific activity $\left[{ }^{11} \mathrm{C}\right]$ raclopride than after the administration of low-specific activity $\left[{ }^{11} \mathrm{C}\right]$ raclopride. Since the concentrations of $\left[{ }^{11} \mathrm{C}\right]$ raclopride in solutions of high- and low-specific activity $\left[{ }^{11} \mathrm{C}\right]$ raclopride are known, PET scans after the administration of high- and low-specific activity $\left[{ }^{11} \mathrm{C}\right]$ raclopride provide the data to estimate the maximal (high-specific activity $\left[{ }^{11} \mathrm{C}\right]$ raclopride) and partial (low-specific activity $\left[{ }^{11} \mathrm{C}\right]$ raclopride) occupancies of dopamine D2 receptors. These data provide the bases to estimate the dopamine D2 receptor density ${ }^{[17,23]}$.

Although $B_{\max }$ elevations have been consistently shown with $\left[{ }^{11} \mathrm{C}\right] \mathrm{NMSP}$, no changes have been demonstrated with $\mathrm{B}_{\max }$ using benzamides such as $\left[{ }^{11} \mathrm{C}\right]$ raclopride or $\left[{ }^{123} \mathrm{I}\right] \mathrm{IBZM}$. However, since benzamides are susceptible to endogenous dopamine, they are used to measure the effect of pharmacological or psychological challenges altering endogenous dopamine levels. There exist several hypotheses to explain the differences in $\mathrm{B}_{\max }$ between $\left[{ }^{11} \mathrm{C}\right]$ raclopride and $\left[{ }^{11} \mathrm{C}\right]$ NMSP. On the one hand, $\left[{ }^{11} \mathrm{C}\right]$ NMSP likely exhibits a preferential affinity for a monomer versus a dimer form of the dopamine receptor ${ }^{[20]}$. Additionally dopamine $\mathrm{D} 2$-like receptors are configured with high $\left(\mathrm{D}_{2}\right.$ high $)$ or low $\left(\mathrm{D}_{2}\right.$ low $)$ affinity for agonists ${ }^{[30]}$. Baboons administered $\left[{ }^{11} \mathrm{C}\right] N$-propyl-norapomorphine, an effective PET radiotracer for dopamine $\mathrm{D}_{2}$ high receptors, exhibit $79 \%$ of the maximal density for dopamine D2-like receptors obtained with $\left[{ }^{11} \mathrm{C}\right]$ raclopride, an antagonist PET radiotracer effective as a PET radiotracer for both high $\left(\mathrm{D}_{2}\right.$ high $)$ or low $\left(\mathrm{D}_{2}\right.$ low $)$ affinity dopamine D2-like receptors ${ }^{[30]}$. Thus, dopamine D2-like receptor binding by endogenous dopamine is better characterized by agonist radiotracers for $\mathrm{D}_{2}$ high, like $\left[{ }^{11} \mathrm{C}\right] \mathrm{NPA}$, than by antagonist radiotracers, like $\left[{ }^{11} \mathrm{C}\right]$ raclopride ${ }^{[30]}$. On the other hand, $\left[{ }^{11} \mathrm{C}\right]$ raclopride probably produces dopamine D2-like receptor internalization. Regardless of the reasons for the differences, meta-analysis has shown that there is a small significant elevation of striatal dopamine D2-like receptors in schizophrenia and there is an association between increased dopamine D2-like receptor density and positive symptoms of 
schizophrenia ${ }^{[20]}$. In accord with the dopamine hypothesis of schizophrenia, chronic reductions in tonic dopamine release in a subgroup of people with schizophrenia result in increments in post-synaptic dopamine D2-like receptor density to compensate for the reduced tonic dopamine release ${ }^{[21]}$.

\subsection{D2-like neuroreceptor imaging throughout the lifespan}

Throughout the human life span (18 to 73 years) the density of D2-like neuroreceptors in the caudate nucleus, the putamen, and the frontal cerebral cortex is inversely proportional to the age of the person ${ }^{[31]}$.

\section{Imaging neuroreceptor systems following pharmacological challenges}

Pharmacological challenges are investigational techniques to evaluate how pharmacological agents affect the densities of neurotransmitters throughout the brain. For example, neuroreceptor imaging estimates how intrasynaptic dopamine is increased by amphetamine and other stimulants and decreased by dopamine-depleting agents including (-)- $\alpha$-methyl-paratyrosine (AMPT), metyrosine (Demser ${ }^{\circledR}$ ). Pharmacological challenges also include the determination of the occupancy of neuroreceptors by putative pharmacological agents ${ }^{[1,20]}$. Confirmation of the phasic elevation of intrasynaptic dopamine in a biological subgroup of people with schizophrenia is provided by an elevation of intrasynaptic dopamine following the administration of stimulants ${ }^{[11,21]}$.

People with schizophrenia are hypothesized to differ from healthy people in both (A) tonic, resting, and (B) phasic, excited states of arousal ${ }^{[21]}$. The population of individuals with the phenotype of schizophrenia likely represents a heterogeneous group with distinct unknown subgroups reflecting different genotypes and other biological markers ${ }^{[20]}$. At rest people are in the tonic, resting, baseline, unstimulated, and unexcited state. The tonic levels of intrasynaptic dopamine of a biological subgroup of people with schizophrenia are hypothesized to be lower than in healthy adults without schizophrenia ${ }^{[3,11,17,20,21,32,33]}$. Additionally the phasic levels of intrasynaptic dopamine of a biological subgroup of people with schizophrenia people with schizophrenia are hypothesized to be higher than healthy adults without schizophrenia ${ }^{[11,17]}$. With excitation, excessive dopaminergic stimulation from the mesencephalon to the limbic striatum likely contributes to the overt positive symptoms of schizophrenia ${ }^{[34]}$.

Pharmacological agents altering the concentrations of intrasynaptic dopamine reduce the dopamine D2-like receptor binding of benzamide radiotracers, including $\left\{(S)-2\right.$-hydroxy-3-[ $\left.{ }^{123} \mathrm{I}\right]$ iodo-6-methoxy- $N$-[(1-ethyl-2-pyrrolidinyl)methyl]benzamide $\}\left(\left[{ }^{123} \mathrm{I}\right] \mathrm{IBZM}\right)$ and $\left[{ }^{11} \mathrm{C}\right]$ raclopride. Dopaminergic agents, such as amphetamine and methylphenidate, produce reduced binding potentials of benzamide radiotracers. In contrast to healthy adults, a biological subgroup of people with schizophrenia demonstrate even greater reductions in the binding potentials of benzamide radiotracers after the administration of dopaminergic pharmacological agents ${ }^{[35-37]}$ probably due to greater occupancy by endogenous dopamine of dopamine D2-like receptors and to alterations of the affinity states ${ }^{[11,20]}$. In accord with the dopamine hypothesis of schizophrenia, the reduced tonic intrasynaptic dopamine likely produces a compensatory increment in the post-synaptic dopamine D2-like receptor density in a group of people with schizophrenia ${ }^{[21]}$. There appear to be subgroups of people with schizophrenia differentiated by positive symptom severity and striatal dopamine D2-like receptor binding. A subgroup of people with more positive symptoms of schizophrenia exhibit greater binding potentials in the striatal dopamine D2-like receptors ${ }^{[20]}$. This subgroup of people with schizophrenia is likely to demonstrate a favorable response to atypical neuroleptics, such as aripiprazole, manifested by a reduction in positive symptoms and an increased occupancy of striatal dopamine D2-like receptors ${ }^{[14,38]}$.

A protocol to perform pharmacological challenges to simulate the tonic and phasic states is utilized to test the hypothesis that alterations in the levels of intrasynaptic dopamine characterize a subgroup of people with schizophrenia (see Figure 2). For this protocol each participant undergoes two positron-emission tomography (PET) scans after the administration of $\left[{ }^{11} \mathrm{C}\right]$ raclopride, a radiotracer that reversibly binds to the dopamine D2 receptors in the brain (see Figure 2) ${ }^{[2,17]}$. Five minutes before the first scan each participant receives an intravenous (IV) injection of $10 \mathrm{~mL}$ of $0.9 \%$ sterile saline $(\mathrm{NaCl})$. Since saline has a negligible effect on the dopamine D2 receptors in the brain, $\left[{ }^{11} \mathrm{C}\right]$ raclopride then binds to most of the 
dopamine D2 receptors in the brain. The corresponding scan thus approximates the density and the distribution of the dopamine D2 receptors in the brain (see Figure 2) ${ }^{[17]}$. Participants are then allowed a rest period before returning for the second scan.

Figure 2. A protocol to assess dopamine in the tonic and phasic states.

Schematic diagram of a procedure employing PET to measure the binding potentials of dopamine D2-like receptors during the tonic resting state after the administration of a placebo, e.g., saline, and during the phasic, excited state after the administration of a dopamine agonist, e.g., amphetamine ${ }^{[39-41]}$.

\section{Methods PET Chronology}

10 min attenuation scan rotating $\left[{ }^{68} \mathrm{Ge}\right]$ source

$5 \mathrm{~min} 10 \mathrm{cc}$ normal saline intravenously (IV)

90 min emission scan following

- $740 \mathrm{MBq}(20 \mathrm{mCl})$ high-specific-activity $\left[{ }^{11} \mathrm{C}\right]$ raclopride IV

- mass $<10$ micrograms

120 min break

$10 \mathrm{~min}$ attenuation scan rotating $\left[{ }^{68} \mathrm{Ge}\right]$ source

$5 \mathrm{~min} 0.3 \mathrm{mg} / \mathrm{kg}$ amphetamine $\mathrm{N}$

90 min emission scan following

- $740 \mathrm{MBq}(20 \mathrm{mCi})$ high-specific-activity $\left[{ }^{11} \mathrm{C}\right]$ raclopride IV

- mass $<10$ micrograms

Five minutes before the second scan each participant receives an intravenous (IV) injection of $0.3 \mathrm{mg} / \mathrm{kg}$ amphetamine. Amphetamine, a dopamine agonist, stimulates the presynaptic neurons in the brain to release dopamine into the synapse. This simulates the maximal physiologic effect of excitement as in the fight or flight response. The endogenous dopamine released in response to amphetamine then occupies many of the postsynaptic dopamine D2 receptors in the brain. Since endogenous dopamine occupies many of the dopamine D2 receptors in the brain, $\left[{ }^{11} \mathrm{C}\right]$ raclopride then binds to the few remaining unoccupied dopamine $\mathrm{D} 2$ receptors in the brain. The corresponding $\left[{ }^{11} \mathrm{C}\right]$ raclopride scan following the administration of amphetamine illuminates only the few unoccupied dopamine D2 receptors in the brain (see Figure 2) ${ }^{[17]}$.

This protocol thus facilitates the estimation of the density and the distribution of the dopamine D2 receptors in the brain in the tonic and phasic states. By administering this protocol to both people with schizophrenia and healthy adults without schizophrenia, one can compare and contrast the density and the distribution of the dopamine D2 receptors in the brain in the tonic and phasic states in people with and without schizophrenia ${ }^{[2,3,17]}$.

Utilizing the protocol of $\left[{ }^{11} \mathrm{C}\right]$ raclopride PET scans after the administration of saline and amphetamine has advanced knowledge about the physiology of healthy adults. In healthy adults plasma cortisol levels were positively associated with dopamine release in the left ventral striatum and the dorsal putamen ${ }^{[39]}$. Additionally in healthy adults, men exhibit markedly more dopamine release in the ventral striatum than women ${ }^{[40]}$. On the other hand, dopamine release did not differentiate between people with and without a family history of alcoholism ${ }^{[41]}$.

The administration of ketamine, a noncompetitive antagonist of the channel receptor for $N$-methyl-D-aspartate (NMDA), a glutamate receptor, to healthy human adults produces increased amphetamine-induced dopamine release comparable to adults with schizophrenia ${ }^{[42]}$.

\section{Estimations of intrasynaptic dopamine}

The estimation of the basal intrasynaptic dopamine in the living human brain is facilitated by the administration of agents to deplete dopamine, including (-)- $\alpha$-methyl-para-tyrosine (AMPT), metyrosine (Demser ${ }^{\circledR}$ ), and reserpine (Harmonyl ${ }^{\circledR}$, Serpalan ${ }^{\circledR}$, and Serpasil $\left.{ }^{\circledR}\right)$. The performance of PET scans to estimate the density and the distribution of dopamine D2-like neuroreceptors after the administration of pharmacologic agents to deplete dopamine provides an optimal 
measurement of the minimal intrasynaptic dopamine in the person. After the pharmacological depletion of dopamine, a biological subgroup of people with schizophrenia display greater binding of dopamine D2-like neuroreceptors than healthy people without schizophrenia. That subgroup is likely to demonstrate the amelioration of positive symptoms with the administration of neuroleptics ${ }^{[35,43]}$. A subgroup of people with unmedicated first-onset schizophrenia likely to achieve an amelioration of positive symptoms with neuroleptics demonstrate correlations of increased dopamine release in both the tonic and phasic states ${ }^{[35,43]}$. These results suggest that the density of dopamine D2-like neuroreceptors is increased in the basal state in a biological subgroup of people with schizophrenia in contrast to healthy

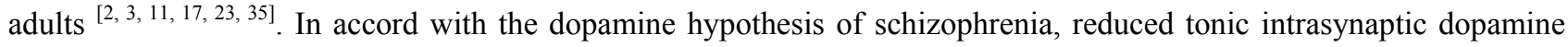
stimulates a compensatory increase in post-synaptic dopamine D2-like neuroreceptor density in a subgroup of people with schizophrenia ${ }^{[21]}$.

The estimation of precursors of dopamine in the presynaptic neuron provides a means to assess the rate of metabolism of dopamine. PET after the administration of $\left[{ }^{18} \mathrm{~F}\right]$ fluoroDOPA $\left(\left[{ }^{18} \mathrm{~F}\right] \mathrm{FDOPA}\right)$ or $\left[{ }^{11} \mathrm{C}\right] \mathrm{DOPA}$ provides a tool to estimate the activity of presynaptic DOPA decarboxylase (DDC). The uptake of DOPA is increased in a biological subgroup of people with schizophrenia and other psychoses in contrast to healthy matched controls subjects ${ }^{[44]}$. This is consistent with the dopamine hypothesis of schizophrenia because the increment in DOPA uptake is likely a response to compensate for the hypothesized low tonic intrasynaptic dopamine concentrations in a subgroup of people with schizophrenia ${ }^{[21]}$ resulting in dopaminergic hyperfunction in a subgroup of people with schizophrenia ${ }^{[20]}$. Additionally a subgroup of untreated people with schizophrenia demonstrate reductions in $\left[{ }^{18} \mathrm{~F}\right] \mathrm{FDOPA}$ in the caudate nucleus and the amygdala in contrast to healthy normal control subjects $\left[{ }^{18} \mathrm{~F}\right]$ FDOPA. In accord with the dopamine hypothesis of schizophrenia, low tonic intrasynaptic dopamine likely produces increased in post-synaptic dopamine D2-like neuroreceptor density in a subgroup of people with schizophrenia ${ }^{[21]}$. Because the post-synaptic dopamine D2-like neuroreceptors are already occupied with endogenous dopamine, $\left[{ }^{18} \mathrm{~F}\right]$ FDOPA uptake in the caudate nucleus and the amygdala DOPA is reduced. These findings substantiate the dopamine hypothesis of schizophrenia manifested by reductions of intrasynaptic dopamine in the tonic state and increments in intrasynaptic dopamine in the phasic state in a group of people with schizophrenia who are likely to improve with the administration of neuroleptics ${ }^{[3,11,17,20,21,33,45]}$.

\section{Presynaptic dopamine in schizophrenia}

Alterations in dopamine in the presynaptic neuron may play a role in schizophrenia. A tool to measure the density and the distribution of the dopamine transporter (DAT) in schizophrenia is the performance of PET after the administration of radiotracers to bind to the DAT, including $\left[{ }^{11} \mathrm{C}\right] \mathrm{WIN} 32,428{ }^{[3,11,17]}$. PET after the administration of (-)-2-betacarbomethoxy-3-beta-(4-fluorophenyl)tropane $\left(\left[{ }^{11} \mathrm{C}\right]\right.$ beta-CFT) demonstrated binding to the DAT in monkeys ${ }^{[46]}$. PET after the administration of scopolamine, a neuronal muscarinic acetylcholine receptor (mAChR) antagonist, or mecamylamine, a neuronal nicotinic acetylcholine receptor (nAChR) antagonist, before the administration of $\left(\left[{ }^{11} \mathrm{C}\right]\right.$ beta-CFT) demonstrated increased DAT binding in monkeys ${ }^{[46]}$. On the other hand, PET demonstrated dose-dependent increased DAT binding in monkeys after the administration of donepezil hydrochloride (Aricept ${ }^{\circledR}$ ), a cholinesterase inhibitor, before the administration of $\left[{ }^{11} \mathrm{C}\right]$ beta-CFT in monkeys ${ }^{[47]}$. Additionally PET after the administration of $N-\left[{ }^{11} \mathrm{C}\right]$ methyl-4-piperidyl benzilate $\left(\left[{ }^{11} \mathrm{C}\right] 4-\mathrm{MPB}\right){ }^{[48]}$ and $(+) N-\left[{ }^{11} \mathrm{C}\right]$ methyl-3-piperidyl benzilate $\left(\left[{ }^{11} \mathrm{C}\right] 3-\mathrm{MPB}\right)$ demonstrated reductions of muscarinic acetylcholine receptor $(\mathrm{mAChR})$ binding in the frontal and temporal cortices and the striata of monkeys proportional to age ${ }^{[46]}$.

\section{Dopamine D2-like neuroreceptors outside the striatum}

While alterations in striatal dopamine have been helpful in the characterization of the pathophysiology of schizophrenia, alterations in dopamine metabolism outside the striatum are also hypothesized to play a role in schizophrenia. The estimation of the density and the distribution of dopamine D2-like neuroreceptors outside the striatum is facilitated by PET after the administration of high-affinity radioligands, including $\left[{ }^{18} \mathrm{~F}\right]$ fallypride and $\left[{ }^{11} \mathrm{C}\right] \mathrm{FLB} 457{ }^{[11]}$. Reductions in dopamine D2-like neuroreceptor binding in the cingulate and temporal cortices, the amygdale, and the thalamus occur in a subgroup of people with schizophrenia ${ }^{[11,23]}$. In accord with the dopamine hypothesis of schizophrenia, the reduced tonic 
dopamine in the synapse led to a compensatory increase in post-synaptic dopamine D2-like neuroreceptor density in a group of people with schizophrenia. Uptake of high-affinity radioligands is likely reduced in a group of people with schizophrenia because the dopamine D2-like neuroreceptors are already occupied by endogenous dopamine ${ }^{[21]}$. There appear to be subgroups of people with schizophrenia differentiated by negative symptom severity and extrastriatal dopamine D2-like receptor binding. The subgroup of patients with more negative symptoms of schizophrenia exhibit reduced binding potentials in the extrastriatal dopamine D2-like receptors ${ }^{[20]}$.

\section{Imaging the serotonin system in schizophrenia}

The beneficial effects of atypical neuroleptics offer further evidence that the serotonin system plays a role in the pathophysiology of schizophrenia. Alterations in the serotonergic system likely contribute to the mood symptoms of people with schizophrenia. Mood symptoms are common in people with schizophrenia. Approximately a tenth of people with schizophrenia commit suicide ${ }^{[34]}$. The mood symptoms of a subgroup of people with schizophrenia likely result from dysfunction of the serotonergic system in conjunction with anomalies of the dopaminergic system.

\section{Imaging serotonin receptors in the brain of people with schizophrenia}

\section{Serotonin 5-HT ${ }_{2 A}$ receptors}

$\left[{ }^{11} \mathrm{C}\right]$ NMSP was utilized to estimate the density and the distribution of cortical serotonin $5-\mathrm{HT}_{2 \mathrm{~A}}$ and striatal dopamine D2-like neuroreceptors in people with schizophrenia ${ }^{[31]}$. Reductions in the density of prefrontal cortical 5- $\mathrm{HT}_{2 \mathrm{~A}}$ receptors have been demonstrated in some drug-naïve people with schizophrenia to confirm autopsy studies ${ }^{[1]}$. $(R)-(+)-4-$ (1-hydroxy-1-(2,3-dimethoxyphenyl)methyl)- $N$-2-(4-fluorophynylethyl)piperidine $\left(\left[{ }^{11} \mathrm{C}\right] \mathrm{MDL} 100,907\right)$, a potent and selective antagonist of the $5-\mathrm{HT}_{2 \mathrm{~A}}$ receptor, utilized for evaluation of $5-\mathrm{HT}_{2 \mathrm{~A}}$ receptors in people with schizophrenia ${ }^{[1]}$, has demonstrated age-related reductions of $5-\mathrm{HT}_{2 \mathrm{~A}}$ receptors in the frontal, temporal, and occipital cortices, hippocampus, and cingulate gyrus of monkeys ${ }^{[49]}$.

Binding of $N$-(2-(4-(2-[ $\left[{ }^{11} \mathrm{C}\right]$ methoxyphenyl)-1-piperazinyl)ethyl)- $N$-(2-pyridyl)cyclohexanecarboxamide ([ $\left.{ }^{11} \mathrm{C}\right] \mathrm{WAY}$ 1006350), a radioligand with high selectivity and high affinity for the $5-\mathrm{HT}_{1 \mathrm{~A}}$ receptors, appears to be inversely proportional to age in the frontal and temporal cortices of monkeys ${ }^{[50]}$.

\section{Serotonin transporter (SERT)}

While autopsy studies have demonstrated reductions of SERT in the frontal cortex and in the cingulate cortex, these findings have not been confirmed in living patients with schizophrenia by SPECT after the administration of $\left[{ }^{123} \mathrm{I}\right]-\beta$-carbomethoxy-3- $\beta$-(4-iodophenyl)-tropane $\left(\left[{ }^{123} \mathrm{I}\right]-\beta\right.$-CIT) and by PET after the administration of $\left[{ }^{11} \mathrm{C}\right]-3$ amino-4-(2-dimethylaminomethylphenylthio)benzonitrile $\left(\left[{ }^{11} \mathrm{C}\right]-(\mathrm{DASB})\right.$, a label for SERT in the midbrain ${ }^{[11,23,51]}$. PET after the administration of $\left[{ }^{11} \mathrm{C}\right](+) \mathrm{McN} 5652$ and $\left[{ }^{11} \mathrm{C}\right](-) \mathrm{McN} 5652$ to monkeys demonstrated age-related reductions throughout the brain, particularly in the thalamus, striatum, and hippocampus $(63.8 \%)^{[52]}$. Further research is needed to clarify the role of SERT in schizophrenia.

\section{The glutamate hypothesis of schizophrenia}

Glutamate, an excitatory neurotransporter, probably participates in the pathogenesis and the pathophysiology of schizophrenia. A group of people with schizophrenia develop chronic reductions in glutamate in the frontal cortex resulting in compensatory elevations of dopamine in the striatum ${ }^{[11]}$. Characterization of the role of glutamate in the pathophysiology of schizophrenia can be enhanced by visualizing the phencyclidine (PCP) site of the receptor channel for $N$-methyl-D-aspartate (NMDA), a glutamate receptor. Although imaging the PCP site of the NMDA receptor channel accomplished by means of PET after the injection of $\left[{ }^{123} \mathrm{I}\right]-N-(1$-naphthyl)- $N$ '-(3-iodophenyl)- $N$-methylguanidine ([ $\left.\left.{ }^{123} \mathrm{I}\right]-\mathrm{CNS}-1261\right)$, a radioligand which attaches to the PCP site in the thalamus and other brain regions, did not differentiate people with schizophrenia from healthy normal controls subjects, administration of clozapine, an atypical neuroleptic, reduced the binding of $\left[{ }^{123} \mathrm{I}\right]-\mathrm{CNS}-1261^{[53]}$. These results suggest that clozapine acts partially through the Published by Sciedu Press 
glutamatergic system. The glutamate hypothesis of schizophrenia proposes that negative symptoms of schizophrenia result from an endogenous hypoglutamatergic state. Glutamate likely also plays in a role in the development of positive symptoms of schizophrenia. This notion is substantiated by the finding that the administration of ketamine (Ketalar $\left.{ }^{\circledR}\right)$, a glutamate agonist blocking the NMDA receptor channel for the PCP site, induces the positive symptoms of schizophrenia in healthy adults ${ }^{[54]}$. Additionally ketamine reduces the binding in the cingulate and retrosplenial cortices after the administration of FLB-457, a radiotracer with high affinity for extrastriatal dopamine. Furthermore, ketamine reduced uptake of $\left[{ }^{11} \mathrm{C}\right]$ raclopride by dopamine D2-like receptors in the striatum while producing hallucinations and other psychotic symptoms ${ }^{[1]}$. On the other hand, ketamine increased the uptake of the dopamine transporter (DAT) in monkeys demonstrated through scans following the administration of (-)-2-beta- $\left[{ }^{11} \mathrm{C}\right]$ carbomethoxy-3-beta-(4-fluorophenyl) tropane $\left(\left[{ }^{11} \mathrm{C}\right]\right.$ beta-CIT) and $N$-(2-fluoroethyl)-2-beta- $\left[{ }^{11} \mathrm{C}\right]$ carbomethoxy-3-beta-(4-iodophenyl) tropane $\left(\left[{ }^{11} \mathrm{C}\right]\right.$ betaCIT-FE) through unknown mechanisms ${ }^{[55]}$. Similar to primates, humans who chronically use ketamine demonstrate dopamine D1 receptor availability in the dorsolateral prefrontal cortex ${ }^{[56]}$. The chronic use of ketamine by humans likely alters the transmission of dopamine in the prefrontal region producing deficits in memory and executive function ${ }^{[56]}$. Therefore, the glutamate hypothesis of schizophrenia proposes that impaired synaptic connectivity resulting from dysfunction of the $N$-methyl-D-aspartate (NMDA) receptors in the prefrontal cortex is supported by (1) the dopamine endophenotype associated with schizophrenia and (2) the production of the positive symptoms of schizophrenia by the chronic administration of ketamine ${ }^{[57]}$.

The administration of ketamine, a noncompetitive antagonist of the channel receptor for NMDA, a glutamate receptor, to healthy human adults produces increased amphetamine-induced dopamine release comparable to adults with schizophrenia ${ }^{[42]}$. The administration of LY 354740, an agonist of the metabotropic glutamate (mGlu) receptor group II to baboons increased amphetamine-induced dopamine release ${ }^{[59]}$. These findings suggest that in primates impaired glutamate transmission likely results in faulty regulation of dopaminergic neurotransmission. A similar phenomenon may occur in humans with the dopamine endophenotype associated with schizophrenia. These findings support the glutamate hypothesis of schizophrenia that a deficit of glutamate function in the dorsolateral prefrontal cortex leads to impaired regulation of the dopaminergic neurotransmission producing the positive symptoms of schizophrenia in humans. Additionally a catechol-O-methyltransferase (COMT) genotype affects cognition and the prefrontal cortex in humans ${ }^{[59]}$. This functional polymorphism for the gene for COMT increases the risk for schizophrenia and other psychoses ${ }^{[59,60]}$. $\left[{ }^{11} \mathrm{C}\right] \mathrm{NNC} 112$, a PET radiotracer for the dopamine D1 receptor, demonstrated greater binding in the cortices, but not the striata, of healthy humans homozygous for the valine allele than healthy humans carriers ${ }^{[61]}$. These finding substantiate the hypothesis that COMT regulates dopaminergic neurotransmission in the cortices and not the striata in healthy humans ${ }^{[61]}$. Future imaging research on the COMT system may elucidate the dysfunction of these pathways in schizophrenia. These findings furthermore provide the bases for considering therapeutic interventions of COMT including tolcapone, an inhibitor of COMT ${ }^{[62]}$.

The glutamate hypothesis of schizophrenia is further substantiated by the finding that people at risk to develop schizophrenia exhibit reduced glutamate in the thalamus and increased glutamine in the anterior cingulate in contrast to healthy adults ${ }^{[63]}$.

\section{The relationship between dopamine D2-like receptor occupancy by dopamine D2-like receptor antagonists and the favorable and unfavorable effects of dopamine D2-like receptor antagonists}

Doses of typical neuroleptics producing the occupancy of 65 to 90 percent of dopamine D2-like receptor are generally clinically effective ${ }^{[2,11,13,15,27]}$. On the one hand, doses of typical neuroleptics occupying less than $60 \%$ of dopamine D2-like receptors are unlikely to produce therapeutic effects in most people with schizophrenia ${ }^{[13]}$. On the other hand, doses of typical neuroleptics occupying greater than $80 \%$ of dopamine D2-like receptors are likely to produce tardive and withdrawal dyskinesias ${ }^{[64]}$ and other movement disorders and other adverse effects in most people with schizophrenia ${ }^{[13]}$. 
While atypical neuroleptics, such as risperidone and olanzepine, appear to have less risk than typical neuroleptics to induce movement disorders with doses producing occupancy of fewer than $80 \%$ of striatal dopamine D2-like receptors, the likelihood of producing extrapyramidal movement disorders increases for both typical and atypical neuroleptics at doses with occupancy of greater than $80 \%$ of striatal dopamine D2-like receptors ${ }^{[11]}$. Special cases exist. Markedly elevated doses of clozapine and quetiapine resulting in the occupancy of 60 to $70 \%$ of dopamine D2-like receptors with minimal extrapyramidal effects often produce anticholinergic, antihistaminic, and $\alpha$-adrenergic adverse effects ${ }^{[11]}$.

Other remarkable agents include dopamine stabilizers, such as aripiprazole (Abilify ${ }^{\circledR}$ ), which ameliorate the positive symptoms of schizophrenia producing fewer extrapyramidal effects when occupying greater than $95 \%$ of dopamine D2-like receptors ${ }^{[1,17,22]}$. PET with $\left[{ }^{18} \mathrm{~F}\right]$ fallypride produces high occupancy of dopamine D2-like receptors throughout the brains of people with schizophrenia and schizoaffective disorder ${ }^{[38]}$. The occupancy of dopamine D2-like receptors was greater in extrastriatal than in striatal regions of the brains of people with schizophrenia and schizoaffective disorder ${ }^{[38]}$. Higher occupancy of striatal dopamine D2-like receptors was correlated with amelioration of positive, but not negative symptoms ${ }^{[38]}$. The simultaneous antagonism and weak agonism of dopamine stabilizers likely results in the favorable therapeutic effects with lesser development of movement disorders ${ }^{[1,17,22]}$. Agents with sufficient efficacy and enough affinity for dopamine D2-like receptors are promising agents for the treatment of schizophrenia. Partial agonists for dopamine D2-like receptors are suitable to function as novel neuroleptics ${ }^{[65]}$.

\section{Future directions}

The glucocorticoid receptor is a necessary tool to initiate and continue many necessary physiological processes ${ }^{[66]}$. The metabolic syndrome occurring in many people with schizophrenia, particularly those taking neuroleptics, suggests that the glucocorticoid receptor may play a role in the pathogenesis and pathophysiology of the disease. The development of transgenic mice with alterations of the glucocorticoid receptors may provide a tool for neuroimaging of the glucocorticoid receptor and related structures ${ }^{[66]}$.

\section{Discussion}

The imaging studies of neuroreceptors in schizophrenia produce results to substantiate the dopamine hypothesis of schizophrenia that reduced tonic intrasynaptic dopamine produces hyperfunction of the dopaminergic system with elevated phasic intrasynaptic dopamine ${ }^{[20,21]}$. There likely exist subgroups of people with schizophrenia characterized by various genotypes and other variations to be clarified. A subgroup of people with schizophrenia exhibit (1) greater positive symptoms of schizophrenia, (2) greater binding potentials in the associative striatal dopamine D2-like receptors ${ }^{[14,67]}$, and (3) a reduction in positive symptoms with neuroleptics ${ }^{[20]}$. Another subgroup of people with schizophrenia may exhibit (1) more negative symptoms of schizophrenia and (2) reduced binding potentials in the extrastriatal dopamine D2-like receptors ${ }^{[20]}$. Research is needed to clarify the genotypes and other characteristics of these subgroups. Future studies using high resolution research tomography (see Figure 1) can likely provide information about subtle structures, including the ventral striatum ${ }^{[68]}$ likely affected in schizophrenia to produce negative symptoms, such as lack of motivation.

\section{Limitations}

This review selected references to substantiate the key concepts in the utilization of nuclear neuroimaging to visualize neurotransmitters, transporters, and receptors. Since a quantitative review was not accomplished, some points may not be representative of published findings. Future contributions may be strengthened by comprehensive reviews of all published research. Such a project is beyond the scope of the current article. 
Additionally the current revisions in the criteria for the diagnosis of schizophrenia may contribute to the heterogeneity of participants in research studies of schizophrenia in the past and the future. Updates to incorporate developments in the fields of radiotracer development, nuclear neuroimaging advances, and the diagnosis and treatment of schizophrenia will merit inclusion in future contributions.

\section{Acknowledgement}

This manuscript is original.

\section{Source(s) of support}

This research was sponsored by the Brain and Behavior Research Foundation (NARSAD), the Essel Foundation, and the National Center for Advancing Translational Science (NCATS) through Grant Number: UL1TR000424. Dr. Brašić is a member of the Medical Advisory Board of the Tourette Syndrome Association of Greater Washington, Silver Spring, Maryland.

\section{References}

[1] Brasic JR. The emergency evaluation of organic brain syndrome. In Proceedings of the Twenty-sixth Annual Conference of Air Force Behavioral Scientists: 1979; Brooke Air Force Base, TX. Edited by Levy RA. Brooke Air Force Base, TX: United States Air Force School of Aerospace Medicine, Aerospace Medical Division (AFSC). 1979: 148-158.

[2] Wong DF, Gründer G, Brašić JR. Brain imaging research: does the science serve clinical practice? Int Rev Psychiatry. 2007; 19: 541-558. PMid:17896234 http://dx.doi.org/10.1080/09540260701564849

[3] Wong DF, Brašić JR. In vivo imaging of neurotransmitter systems in neuropsychiatry. Clin Neurosci Res. 2001 ; 1: 35-45. http://dx.doi.org/10.1016/S1566-2772(00)00005-0

[4] Wright IC, Rabe-Hesketh S, Woodruff PW, David AS, Murray RM, Bullmore ET. Meta-analysis of regional brain volumes in schizophrenia. Am J Psychiatry. 2000; 157: 16-25. PMid:10618008

[5] Ellison-Wright I, Glahn DC, Laird AR, Thelen SM, Bullmore E. The anatomy of first-episode and chronic schizophrenia: an anatomical likelihood estimation meta-analysis. Am J Psychiatry. 2008; 165: 1015-1023. PMid:18381902 http://dx.doi.org/10.1176/appi.ajp.2008.07101562

[6] Wong DF, Potter WZ, Brašić JR. Proof of concept: models of drug development for humans. In Neuropsychopharmacology: The Fifth Generation of Progress, K. L. Davis, D. Charney, J. T. Coyle, C. Nemeroff, eds. Baltimore: Lippincott Williams \& Wilkins, 2002: 457-473.

[7] Alexander M, Brašić JR. The diagnosis of esophageal cancer by 2-deoxy-2-F-18 fluoro-D-glucose positron emission tomography (F-18 FDG PET). Clin Nucl Med. 2006; 31: 566-567. PMid:16921288 http://dx.doi.org/10.1097/01.rlu.0000233350.01580.c2

[8] Sossi V, de Jong HWAM, Barker WC, Bloomfield P, Burbar Z, Camborde ML, et al. The second generation HRRT - a multicentre scanner performance investigation. Nuclear Science Symposium Conference Record. 2005 Institute of Electrical and Electronics Engineers (IEEE). 2005: 2195-2199.

[9] Wong DF, Maini A, Rousset OG, Brašić JR. Positron emission tomography: a tool for identifying the effects of alcohol dependence on the brain. Alcohol Res Health. 2003; 27: 161-173. http://pubs.niaaa.nih.gov/publications/arh27-2/161-173.pdf Accessed online on June 29, 2012.

[10] Feighner JP, Robins E, Guze SB, Woodruff RA, Jr, Winokur G, Munoz R. Diagnostic criteria for use in psychiatric research. Arch Gen Psychiatry. 1972; 26: 57-63. PMid:5009428 http://dx.doi.org/10.1001/archpsyc.1972.01750190059011

[11] Wong DF, Gründer G, Cascella NG, Brašić JR. Molecular brain imaging in schizophrenia. In Kaplan \& Sadock’s Comprehensive Textbook of Psychiatry, 9th ed., B. J. Sadock, V. A. Sadock, P. Ruiz, eds., Philadelphia: Lippincott Williams \& Wilkins. 2009: 1519-1530. PMid:18718828

[12] Wagner HN, Jr, Burns HD, Dannals RF, Wong DF, Langstrom B, Duelfer T, et al. Imaging dopamine receptors in the human brain by positron tomography. Science. 1983; 221: 1264-1266. PMid:6604315 http://dx.doi.org/10.1126/science.6604315

[13] Howes OD, Egerton A, Allan V, McGuire P, Stokes P, Kapur S. Mechanisms underlying psychosis and antipsychotic treatment response in schizophrenia: insights from PET and SPECT imaging. Curr Pharm Des. 2009; 15: 2550-2559. PMid:19689327 http://dx.doi.org/10.2174/138161209788957528 
[14] Howes OD, Montgomery AJ, Asselin MC, Murray RM, Valli I, Tabraham P, et al. (2009). Elevated striatal dopamine function linked to prodromal signs of schizophrenia. Arch Gen Psychiatry 2009; 66: 13-20. PMid:19124684 http://dx.doi.org/10.1001/archgenpsychiatry.2008.514

[15] Howes OD, Kapur S. The dopamine hypothesis of schizophrenia: version III--the final common pathway. Schizophr Bull. 2009; 35: 549-562. PMid:19325164 http://dx.doi.org/10.1093/schbul/sbp006

[16] Snyder SH. Dopamine receptor excess and mouse madness. Neuron. 2006; 49: 484-485. PMid:16476659 http://dx.doi.org/10.1016/j.neuron.2006.02.002

[17] Wong DF, Brašić JR. Progress in the neuropsychiatry of schizophrenia. Psychiatr Times March. 2005; 22(3): 57, 58, 60.

[18] Carlsson A. Birth of neuropsychopharmacology_impact on brain research. Brain Res Bull. 1999; $50: 363$. http://dx.doi.org/10.1016/S0361-9230(99)00106-9

[19] Carlsson A, Waters N, Carlsson ML. Neurotransmitter interactions in schizophrenia---therapeutic implications. Biol Psychiatry. 1999; 46: 1388-1395. http://dx.doi.org/10.1016/S0006-3223(99)00117-1

[20] Smith GS, Koppel J, Goldberg S. (2003). Applications of neuroreceptor imaging to psychiatry research. Psychopharmacol Bull. 2003; 37: 26-65. PMid:15131516

[21] Grace AA. Phasic versus tonic dopamine release and the modulation of dopamine system responsivity: a hypothesis for the etiology of schizophrenia. Neuroscience. 1991; 41: 1-24. http://dx.doi.org/10.1016/0306-4522(91)90196-U

[22] Gründer G, Carlsson A, Wong DF. Mechanism of new antipsychotic medications: occupancy is not just antagonism. Arch Gen Psychiatry. 2003; 60: 974-977. PMid:14557141 http://dx.doi.org/10.1001/archpsyc.60.10.974

[23] Wong DF, Brašić JR, Cascella N. Neuroreceptor imaging of schizophrenia. In Understanding Neuropsychiatric Disorders: Insights from Neuroimaging. M. E. Shenton, B. I. Turetsky, eds. Cambridge, UK: Cambridge University Press. 2011: 78-87.

[24] Kellendonk C, Simpson EH, Polan HJ, Malleret G, Vronskaya S, Winiger V, et al. Transient and selective overexpression of dopamine D2 receptors in the striatum causes persistent abnormalities in prefrontal cortex functioning. Neuron. 2006; 49: 603-615. PMid:16476668 http://dx.doi.org/10.1016/j.neuron.2006.01.023

[25] Seamans JK, Gorelova N, Durstewitz D, Yang CR. Bidirectional dopamine modulation of GABAergic inhibition in prefrontal cortical pyramidal neurons. J Neurosci. 2001; 21: 3628-3638. PMid:11331392

[26] Innis RB, Cunningham VJ, Delforge J, Fujita M, Gjedde A, Gunn RN, et al. Consensus nomenclature for in vivo imaging of reversibly binding radioligands. J Cereb Blood Flow Metab. 2007; 27: 1533-1539. PMid:17519979 http://dx.doi.org/10.1038/sj.jcbfm.9600493

[27] Farde L, Hall H, Ehrin E, Sedvall G. Quantitative analysis of D2 dopamine receptor binding in the living human brain by PET. Science. 1986; 231: 258-261. PMid:2867601 http://dx.doi.org/10.1126/science.2867601

[28] Wong DF, Wagner HN, Jr, Tune LE, Dannals RF, Pearlson GD, Links JM, et al. Positron emission tomography reveals elevated D2 dopamine receptors in drug-naive schizophrenics. Science. 1986; 234: 1558-1563. PMid:2878495 http://dx.doi.org/10.1126/science.2878495

[29] Wong DF. In vivo imaging of D2 dopamine receptors in schizophrenia: the ups and downs of neuroimaging research. Arch Gen Psychiatry. 2002; 59: 31-34 [comment]. PMid:11779279 http://dx.doi.org/10.1001/archpsyc.59.1.31

[30] Narendran R, Hwang DR, Slifstein M, Hwang Y, Huang Y, Ekelund J, et al. (2005b). Measurement of the proportion of $\mathrm{D}_{2}$ receptors configured in state of high affinity for agonists in vivo: a positron emission tomography study using $\left[{ }^{11} \mathrm{C}\right] N$-propyl-norapomorphine and $\left[{ }^{11} \mathrm{C}\right]$ raclopride in baboons. J Pharmacol Exp Ther. 2005; 315: 80-90. PMid:16014571 http://dx.doi.org/10.1124/jpet.105.090068

[31] Wong DF, Wagner HN, Jr, Dannals RF, Links JM, Frost JJ, Ravert HT, et al. Effects of age on dopamine and serotonin receptors measured by positron tomography in the living human brain. Science. 1984; 226: 1393-1396. PMid:6334363 http://dx.doi.org/10.1126/science.6334363

[32] Grace AA. The tonic/phasic model of dopamine system regulation: its relevance for understanding how stimulant abuse can alter basal ganglia function. Drug Alcohol Depend. 1995; 37: 111-129. http://dx.doi.org/10.1016/0376-8716(94)01066-T

[33] Grace AA, Moore H, O'Donnell P. The modulation of corticoaccumbens transmission by limbic afferents and dopamine: a model for the pathophysiology of schizophrenia. Adv Pharmacol. 1998; 42: 721-724. http://dx.doi.org/10.1016/S1054-3589(08)60849-2

[34] Lewis DA, Lieberman JA. Catching up on schizophrenia: natural history and neurobiology. Neuron. 2000; 28 : $325-334$. http://dx.doi.org/10.1016/S0896-6273(00)00111-2

[35] Abi-Dargham A, Rodenhiser J, Printz D, Zea-Ponce Y, Gil R, Kegeles LS, et al. (2000). Increased baseline occupancy of D2 receptors by dopamine in schizophrenia. Proc Natl Acad Sci U S A. 2000; 97: 8104-8109. PMid:10884434 http://dx.doi.org/10.1073/pnas.97.14.8104

[36] Laruelle M. Imaging dopamine transmission in schizophrenia. A review and meta-analysis. Q J Nucl Med. 1998; $42: 211-221$. PMid:9796369 
[37] Laruelle M, Abi-Dargham A, van Dyck CH, Gil R, D'Souza CD, Erdos J, et al. Single photon emission computerized tomography imaging of amphetamine-induced dopamine release in drug-free schizophrenic subjects. Proc Natl Acad Sci U S A. 1996; 93: 9235-9240. PMid:8799184 http://dx.doi.org/10.1073/pnas.93.17.9235

[38] Kegeles LS, Slifstein M, Frankle WG, Xu X, Hackett E, Bae SA, et al. Dose-occupancy study of striatal and extrastriatal dopamine D2 receptors by aripiprazole in schizophrenia with PET and $\left[{ }^{18} \mathrm{~F}\right]$ fallypride. Neuropsychopharmacology. 2008; 33: $3111-3125$. PMid:18418366 http://dx.doi.org/10.1038/npp.2008.33

[39] Oswald LM, Wong DF, McCaul M, Zhou Y, Kuwabara H, Choi L, et al. Relationships among ventral striatal dopamine release, cortisol secretion, and subjective responses to amphetamine. Neuropsychopharmacology. 2005; 30: 821-832. PMid:15702139

[40] Munro CA, McCaul ME, Wong DF, Oswald LM, Zhou Y, Brasic J, et al. Sex differences in striatal dopamine release in healthy adults. Biol Psychiatry. 2006; 59: 966-974. PMid:16616726 http://dx.doi.org/10.1016/j.biopsych.2006.01.008

[41] Munro CA, McCaul ME, Oswald LM, Wong DF, Zhou Y, Brasic J, et al. Striatal dopamine release and family history of alcoholism. Alcohol Clin Exp Res. 2006; 30: 1143-1151. PMid:16792561 http://dx.doi.org/10.1111/j.1530-0277.2006.00130.x

[42] van Berckel BN, Oranje B, van Ree JM, Verbaten MN, Kahn RS. The effects of low dose ketamine on sensory gating, neuroendocrine secretion and behavior in healthy human subjects. Psychopharmacology (Berl). 1998; 137: $271-281$. http://dx.doi.org/10.1007/s002130050620

[43] Abi-Dargham A, van de Giessen E, Slifstein M, Kegeles LS, Laruelle M. Baseline and amphetamine-stimulated dopamine activity are related in drug-naïve schizophrenic subjects. Biol Psychiatry. 2009; 65: 1091-1093. PMid:19167701 http://dx.doi.org/10.1016/j.biopsych.2008.12.007

[44] Bose SK, Turkheimer FE, Howes OD, Mehta MA, Cunliffe R, Stokes PR, et al. Classification of schizophrenic patients and healthy controls using [18F] fluorodopa PET imaging. Schizophr Res. 2008; 106: 148-155. PMid:18849151 http://dx.doi.org/10.1016/j.schres.2008.09.011

[45] Valli I, Howes O, Tyrer P, McGuire P, Grasby PM. Longitudinal PET imaging in a patient with schizophrenia did not show marked changes in dopaminergic function with relapse of psychosis. Am J Psychiatr. 2008; 165: 1613-1614. [letter]. PMid:19047337 http://dx.doi.org/10.1176/appi.ajp.2008.08071109

[46] Tsukada H, Kakiuchi T, Nishiyama S, Ohba H, Sato K, Harada N, et al. Age differences in muscarinic cholinergic receptors assayed with $(+) \mathrm{N}-[(11) \mathrm{C}]$ methyl-3-piperidyl benzilate in the brains of conscious monkeys. Synapse. 2001; 41: $248-257$. PMid:11418938 http://dx.doi.org/10.1002/syn.1082

[47] Tsukada H, Nishiyama S, Ohba H, Sato K, Harada N, Kakiuchi T. Cholinergic neuronal modulations affect striatal dopamine transporter activity: PET studies in the conscious monkey brain. Synapse. 2001; 42: 193-195. PMid:11746716 http://dx.doi.org/10.1002/syn.10003

[48] Kakiuchi T, Ohba H, Nishiyama S, Sato K, Harada N, Nakanishi S, et al. Age-related changes in muscarinic cholinergic receptors in the living brain: a PET study using $\mathrm{N}$-[11C]methyl-4-piperidyl benzilate combined with cerebral blood flow measurement in conscious monkeys. Brain Res. 2001 ;916: 22-31. http://dx.doi.org/10.1016/S0006-8993(01)02859-1

[49] Kakiuchi T, Nishiyama S, Sato K, Ohba H, Nakanishi S, Tsukada H. Age-related reduction of $\left[{ }^{11} \mathrm{C}\right]$ MDL100,907 binding to central 5-HT $2 \mathrm{~A}$ receptors: PET study in the conscious monkey brain. Brain Res. 2000; 883: 135-142.

http://dx.doi.org/10.1016/S0006-8993(00)02881-X

[50] Tsukada H, Kakiuchi T, Nishiyama S, Ohba H, Harada N. Effects of aging on 5-HT(1A) receptors and their functional response to 5-HT(1a) agonist in the living brain: PET study with [carbonyl-(11)C]WAY-100635 in conscious monkeys. Synapse. 2001; 42: 242-251. PMid:11746722 http://dx.doi.org/10.1002/syn.10011

[51] Frankle WG, Narendran R, Huang Y, Hwang DR, Lombardo I, Cangiano C, et al. Serotonin transporter availability in patients with schizophrenia: a positron emission tomography imaging study with $\left[{ }^{11} \mathrm{C}\right] \mathrm{DASB}$. Biol Psychiatry. 2005; 57: $1510-1516$. PMid:15953487 http://dx.doi.org/10.1016/j.biopsych.2005.02.028

[52] Kakiuchi T, Tsukada H, Fukumoto D, Nishiyama S. Effects of aging on serotonin transporter availability and its response to fluvoxamine in the living brain: PET study with $\left[{ }^{11} \mathrm{C}\right](+) \mathrm{McN} 5652$ and $\left[{ }^{11} \mathrm{C}\right](-) \mathrm{McN} 5652$ in conscious monkeys. Synapse. 2001; 40: 170-179. PMid:11304754 http://dx.doi.org/10.1002/syn.1039

[53] Bressan RA, Erlandsson K, Stone JM, Mulligan RS, Krystal JH, Ell PJ, et al. Impact of schizophrenia and chronic antipsychotic treatment on $\left[{ }^{123} \mathrm{I}\right] \mathrm{CNS}-1261$ binding to N-methyl-D-aspartate receptors in vivo. Biol Psychiatry. 2005; 58: 41-46. PMid:15992521 http://dx.doi.org/10.1016/j.biopsych.2005.03.016

[54] Krystal JH, Karper LP, Seibyl JP, Freeman GK, Delaney R, Bremner JD, et al. Subanesthetic effects of the noncompetitive NMDA antagonist, ketamine, in humans. Psychotomimetic, perceptual, cognitive, and neuroendocrine responses. Arch Gen Psychiatry. 1994; 51: 199-214. PMid:8122957 http://dx.doi.org/10.1001/archpsyc.1994.03950030035004 
[55] Tsukada H, Nishiyama S, Kakiuchi T, Ohba H, Sato K, Harada N. Ketamine alters the availability of striatal dopamine transporter as measured by $\left[{ }^{11} \mathrm{C}\right] \beta-\mathrm{CFT}$ and $\left[{ }^{11} \mathrm{C}\right] \beta-\mathrm{CIT}-\mathrm{FE}$ in the monkey brain. Synapse. 2001; 42: 273-280. PMid:11746726 http://dx.doi.org/10.1002/syn.10012

[56] Narendran R, Frankle WG, Keefe R, Gil R, Martinez D, Slifstein M, et al. Altered prefrontal dopaminergic function in chronic recreational ketamine users. Am J Psychiatry. 2005; 162: 2352-2359. PMid:16330601 http://dx.doi.org/10.1176/appi.ajp.162.12.2352

[57] Laruelle M, Frankle WG, Narendran R, Kegeles LS, Abi-Dargham A. Mechanism of action of antipsychotic drugs: from dopamine D(2) receptor antagonism to glutamate NMDA facilitation. Clin Ther. 2005; 27(Suppl A): S16-S24. PMid:16198197 http://dx.doi.org/10.1016/j.clinthera.2005.07.017

[58] van Berckel BN, Kegeles LS, Waterhouse R, Guo N, Hwang DR, Huang Y, et al. Modulation of amphetamine-induced dopamine release by group II metabotropic glutamate receptor agonist LY354740 in non-human primates studied with positron emission tomography. Neuropsychopharmacology. 2006; 31: 967-977. PMid:16177807 http://dx.doi.org/10.1038/sj.npp.1300902

[59] Akil M, Kolachana BS, Rothmond DA, Hyde TM, Weinberger DR, Kleinman JE. Catechol-O-methyltransferase genotype and dopamine regulation in the human brain. J Neurosci. 2003; 23: 2008-2013. PMid:12657658

[60] Kane JM, Perlis RH, Malhotra AK. Clinical insights into pharmacogenetics and schizophrenia, part 2. J Clin Psychiatry. 2008; 69: 1006-1013. PMid:18683996 http://dx.doi.org/10.4088/JCP.v69n0618

[61] Slifstein M, Kolachana B, Simpson EH, Tabares P, Cheng B, Duvall M, et al. COMT genotype predicts cortical-limbic D1 receptor availability measured with [ $\left.{ }^{11} \mathrm{C}\right] \mathrm{NNC} 112$ and PET. Mol Psychiatry. 2008; 13: 821-827. PMid:18317466 http://dx.doi.org/10.1038/mp.2008.19

[62] Truong DD. Tolcapone: review of its pharmacology and use as adjunctive therapy in patients with Parkinson's disease. Clin Interv Aging. 2009; 4: 109-113. PMid:19503773 http://dx.doi.org/10.2147/CIA.S3787

[63] Stone JM, Day F, Tsagaraki H, Valli I, McLean MA, Lythgoe DJ, et al. Glutamate dysfunction in people with prodromal symptoms of psychosis: relationship to gray matter volume. Biol Psychiatry. 2009; 66: 533-539. PMid:19559402 http://dx.doi.org/10.1016/j.biopsych.2009.05.006

[64] Brasic JR, Bronson B, Chun TT. Tardive dyskinesia. eMedicine from WebMD, Updated February 9, 2012. Available from: http://emedicine.medscape.com/article/1151826-overview Accessed online on June 30, 2012.

[65] Inoue A, Nakata Y. Strategy for modulation of central dopamine transmission based on the partial agonist concept in schizophrenia therapy. Jpn J Pharmacol. 2001; 86: 376-380. PMid:11569610 http://dx.doi.org/10.1254/jjp.86.376

[66] Kellendonk C, Tronche F, Reichardt HM, Schütz G. Mutagenesis of the glucocorticoid receptor in mice. J Steroid Biochem Mol Biol. 1999; 69: 253-259. http://dx.doi.org/10.1016/S0960-0760(99)00041-2

[67] Egerton A, McGuire PK, Howes OD. Functionally defined regions may aid interpretation of striatal dopamine elevation in schizophrenia. Schizophr Res. 2009; 109: 200. [letter] PMid:19250801 http://dx.doi.org/10.1016/j.schres.2009.02.004

[68] Haber SN, McFarland NR. The concept of the ventral striatum in nonhuman primates. Ann N Y Acad Sci. 1999; 877: $33-48$. PMid:10415641 http://dx.doi.org/10.1111/j.1749-6632.1999.tb09259.x 